\title{
INDIAN ENVIRONMENTAL POLITICS: AN INTERVIEW
}

\author{
Transforming Cultures eJournal, \\ Vol. 5 No 1 June 2010 \\ http://epress.lib.uts.edu.au/journals/TfC
}

\section{Amita Baviskar}

\begin{abstract}
Amita Baviskar is a key analyst of environmental politics and culture in India. Her research and publications have addressed the intense conflicts over water, caste and class arising from the Narmada River dams, and she is currently working on the politics of urban conservation and contestations over public space in Delhi in the lead up to the Commonwealth Games.

Her publications include her monograph: In the Belly of the River: Tribal Conflicts over Development in the Narmada Valley. (Oxford University Press, 1995); her co-authored book: Untouchability in Rural India, (Sage Publications: New Delhi 2006) and her edited: Waterscapes: The cultural politics of a natural resource, (Uttaranchal: Permanent Black, 2007)

This interview was conducted by Nick McClean during Amita's visit to Sydney for the Cities Nature Justice conference, held 10 - 12 December, 2008, at the University of Technology Sydney. Nick McClean is currently undertaking $\mathrm{PhD}$ research at ANU on comparative approaches to conservation in Australia and India.
\end{abstract}

Amita I'm a sociologist at the Institute of Economic Growth in Delhi and most of my work deals with the cultural politics of environment and development in India. I first started out as an amateur naturalist working with Kalpavriksh, an environmental action group in Delhi, which was a group of students in school and college. We were interested in trying to understand environmental problems and conflicts and doing something to resolve them, and that was my first exposure to the ways in which environmental questions in India were not just about, protecting endangered species, etc., or protecting green areas in cities, but were also issues of social justice. This realisation came about because we would often travel to other parts of India where there were groups involved with struggles to secure rights to their environment, and the environment was something that they used and depended on for 
their livelihood as much as a source of joy, identity, belonging and other cultural meanings.

Nick: I wonder if you can tell us a bit about the work that you did in the Narmada Valley. You wrote your book In the Belly of the River about that. Could you explain to me a little bit about the process you went through in order to write that book.

Amita Yes. Well I started off with a fairly straightforward understanding that the campaign against the Narmada Dam, which was going to displace hundreds of thousands of families, both caste Hindu peasants as well as Adivasis (Scheduled Tribes, or 'indigenous people'), was a social movement that was profoundly important because not only did it make specific claims to a certain place and the life and livelihoods that were associated with that place, but it also raised really important and far-reaching questions about development, the pattern of industrialisation and urbanisation that independent India had chosen to embark on, and the ways in which that pattern was neither ecologically sustainable, nor socially just. So the anti-dam movement was a really important embodiment of a critique of development, of a struggle that brought together very different kinds of constituencies to fight against a dam that was iconic of the way in which India had been going down the wrong path since Independence in 1947.

Nick: I was interested to note when I was leafing through your book that you said that you yourself went there with I guess some ideas about the Adivasi relationship to the environment which you found to be somewhat different to what they actually were, and that you found the situation to be more contradictory than you'd anticipated. I wonder if you could elaborate a little bit on that process for me.

Amita Well I went there with this fairly straightforward understanding that I'd find Adivasis who lived in harmony with nature, who used resources sustainably, who had a cultural attachment to the land and to the river, and that that was the basis of their claim to place and their resistance against this displacement. What I found in the Narmada valley was much more complicated because, in fact, Adivasis had been so drastically ground down by the Government as well as by upper caste traders and Government officials that they were not in any position to actually present an alternative 
vision of development at all. In fact, many of their own livelihood practices were not particularly ecologically sustainable either. And so that led me to this argument that I develop in the book that, in fact, many environmental movements make claims about Adivasis which are in fact unfounded on the actual circumstances of Adivasi oppression and which in fact don't do justice to the real resource struggles and challenges that Adivasis face in their everyday life. And what social movements need to do is, in fact, recognise that Adivasis need to be supported in other kinds of ways -beyond simply a defence of their status quo-to make their livelihood practices more ecologically and economically sustainable. The most accurate description of Adivasi practices in the Narmada valley would be 'environmentalist by default', because although they do not use forest lands in sustainable ways (cultivating, as they do, hill-slopes prone to erosion), the lives they live today are still way better than what the Government proposes to do with the valley, which is to drown it. So, in the larger scheme of things, Adivasis appear to be environmentalists. But my book then also ended up being a critique of middle-class environmentalists, especially those who live in cities, and their notion of Adivasis as people who must always perform the role of the ecologically noble savage. So the moment Adivasis stop doing that, when they express the desire for some material improvement in their extremely impoverished lives, and do so by cutting trees or cultivating friable hill lands, then suddenly they become no longer worthy of environmentalists' support. So it is only the Adivasi who lives in the Narmada Valley and who has a cultural attachment to that land, and who has myths about the land, who lives in the forest, is thought of as, virtuous and worthy of political support. Once that Adivasi lands up in an city neighbourhood, after being dispossessed, and lives on the pavement and, is essentially an ecological refugee, then that same Adivasi becomes the focus of middle-class anger, suspicion, distrust, because the intelligentsia doesn't want poor people living in slums next to them. So, there's a particular kind of environmentalist mindset which romanticises Adivasi poverty as long as it's far away, 'rooted in nature', but which doesn't want to deal with the links between middle-class lifestyles and rural resource degradation, or recognise their own complicity in social relations that allow a certain kind of poverty to exist and get reproduced.

Nick: This form of middle class environmentalism is something you discussed the other day in your presentation at the conference in terms of recent issues 
in Delhi. That was a concept that I was quite interested in personally. I wonder if you could elaborate on that in the context that you were discussing the other day.

Amita I was talking about it in terms of how, primarily, environmentalism in India has been characterised as environmentalism of the poor, that many struggles over natural resources have occurred in the countryside and have involved poor people fighting to hold on to resources that they earlier had access to, and that has meant fighting against the Government or mining companies, or against large dams etc. And so, in rural struggles, a connection has often been made between people's claims as human rights issues in terms of social justice and issues of ecological sustainability. In the urban situation, what we see more often is not this kind of environmentalism of the poor, but a bourgeois environmentalism where the middle classes try to pursue the creation of an ordered space which is beautiful, gracious, which fulfils their desire for a privileged lifestyle, where nature is controlled and made available for recreation. An environmentalism of that sort is very hostile to the poor and, as I've shown in my work in Delhi, a lot of the actions which have directly affected the poor, for instance the closure of factories which has thrown people out of work, or the evictions and demolitions of slums, which have thrown people out of their homes, have happened because middle-class environmentalists have gone to court and asked the courts to act against air pollution, or water pollution, or the incidence of disease and son on. And court orders have generally taken the form of actions that have directly ended up hurting the poor rather than anybody else. So, I'm also concerned about the way in which bourgeois environmentalists claim to speak for the 'public interest', or for the nation, and often that ends up hurting people who are already quite vulnerable and the working class in particular, who then cannot claim the same kinds of rights. So I'm concerned about the way in which the discourse of public interest and citizenship has come to be monopolised by bourgeois environmentalists to further their own interests. So, yes, cleaning the air is great for everybody, but not if it means that tens of thousands of people can't feed themselves because they've lost their jobs or, yes it's much nicer that there shouldn't be slums in Delhi, but not if it means that you simply push the people who are compelled to live in slums out of the city and make them homeless and force them to live far on the outer periphery, away from their sources of livelihood. 
Nick: Is this something which you've always had a parallel interest in, or is your awareness of the social justice issues surrounding environmentalism grown as your engagement with environmentalism has gone on and your learning has progressed, I guess.

Amita I think the early, formative experience for me was my involvement with this environmental action group in school, and then in college. It was a very unusual group in a sense because it started off as a group of upper-middle-class nature lovers, and in that sense, we could also have been bourgeois environmentalists too -- in fact, in some senses, we were -- but it was the process of going out and engaging with groups who had very different concerns that forced us out of our conventional understanding of, 'oh, we must save trees' and, 'endangered species must be protected', etc., to think much more about the sustainability of our own lifestyles, the sustainability of our country's growth trajectory, and the implications of that for conservation in general. Over the years, as I've seen economic and social inequalities in India worsen rather than get any better, I've become a little bit more, I wouldn't say cynical, but I've certainly become a little less concerned about conservation in the sense of, you know, the future of the planet. I worry about the really desperate problems that affect people directly in the present, and I think I'm willing to let the future wait. So much of conservation has directly excluded poor people by saying, oh we need to save the planet by creating protected areas or reserving forests, or, you know, claiming to speak for this endangered species or that. And those are really acts of presumption, and if we can conserve without making anybody else worse off, then it's all right but, only too often, steps to preserve the environment end up being at the cost of social justice, without really targeting the far more ecologically destructive practices of the affluent and powerful sections of society, the same class from which bourgeois environmentalists come. And that may well be the case with what's going to happen with climate change as well, that the measures are going to make a lot of poor people even worse off than they already are.

Nick: $\quad$ They're obviously very difficult issues that you're trying to face up and understand. I wonder, through the many years that you've been dealing with these issues, what is it about your work that actually keeps you going from year to year and actually keeps you coming back to keep working on these issues? 
Amita Well, at times it's just hugely depressing in the sense that I worked in the Narmada Valley for a long time, and that social struggle was profoundly exhilarating and exciting and inspiring, and yet, the Supreme Court of India said that the dam should be built. It was a setback of a kind one can't even imagine, and I think it really just crushed a lot of people. The situation in Delhi is also, in many ways, extremely challenging because, for a variety of reasons, there's been no social movement, and it seems like we are making very little difference in terms of deflecting or stopping this steamroller that's just going on and on and transforming the city in which we live. So that makes it hard to be optimistic, but I think people just carry on, carry on living and carry on struggling because they don't know how to do it any other way, and I find that, in its own way, really inspiring that one keeps going, taking heart from what's a constant process, rather than focus on some sort of goal that's always on the horizon. Yeah, it's tough, but, you know, people deal with it.

Nick: $\quad$ Amita Baviskar, thank you for your time.

Amita Thank you. 